sectioning. These facts incline me to the view that the physical condition of the vitamin varies over a period of time, dependent upon factors as yet unknown, certainly modified by the physiological state of the adrenal cells, and undoubtedly modified to a certain extent by the reagents used upon the gland. Grofrrey Bourne

(Hackett Research Student). Department of Biology,

University of Western Australia, Perth.

Aug. 25.

1 Nature, 131, 874, June 17, 1933.

Bourne, Aus. J. Exp. Biol. Med. Sci., in press.

\section{The New Volcanic Island, Krakatoa}

To a botanist or zoologist the birth of a new island from beneath the sea is an event of considerable interest. A number of questions occur to him and he will almost inevitably speculate as to the first forms of life to colonise it, and the date of their appearance. In Dr. W. Docters van Leeuwen's interesting letter, published in NATURE of October 28, a list of the first seedlings to colonise Anak Krakatoa IV is given. 'These were collected in May 1932, but his reference to an observation four months earlier indicates that seedlings were present at least as early as seventeen months after the island first began to appear above sea-level.

Happening to be in the vicinity of the Krakatoa Islands in February 1931, I took advantage of assistance offered me by the volcanological service to stay four days there, and in the course of this stay I crossed the three miles separating Anak Krakatoa IV from the other islands. On the black volcanic ash composing the islands black cinders and white pumice were sprinkled, whilst along its shores driftwood and other vegetable debris were strewn. Careful search showed me that at this date, six months after the first appearance of the island, none of the plant seeds which were in evidence had taken root or germinated, but in spite of this a small fauna had already established itself. This consisted of a collembolan (Mesira calolepis Börner) and a beetle (Anthicus oceanicus Laf.), both in abundance amongst the decaying vegetation, and three species of spider (Trochosa reimoseri Bris., Ctenus periculosus Bris. and Maso krakatauensis Bris.). Three other species of insect-a leaf-mining moth (Cosmopteryx), a mosquito and a male ant (Camponotus (Tanaemyrmex) variegatus, F. Smith)-were probably stray arrivals which could not at that time establish themselves.

In the Proceedings of the Zoological Society, Pt. 4, 1931, I attempted to summarise our knowledge of the present fauna of the Krakatoa Islands, and a list of the spiders I collected there myself is appearing in a forthcoming part of the same Proceedings, but here it may be interesting to record that in May 1884, nine months after the terrific eruption which destroyed all the animal and plant life, the only sign of life which Cotteau could find was a solitary spider, whilst later in the same year Verbeek saw a few blades of grass. To-day there are nearly 300 kinds of plants and about 700 arthropods, apart from birds, bats, rats, reptiles, crustaceans, molluscs and worms.

37, Holland Park,

W. S. BRISTOWE.
Flint Implements of Early Magdalenian Age from Deposits Underlying the Lower Estuarine Clay, Co. Antrim

Some time ago (August 16, 1930, and May 14, 1932) there appeared in NATURE two short statements re. lating to my discovery both on Islandmagee and at Lame, Co. Antrim, of flint implements of Late Magdalenian age within the Lower Estuarine Clay which underlies the gravels of the 25 -foot raised beach.

Lately, by reason of the construction of a small har. bour on the western side of Islandmagee, I have been afforded an exceptional opportunity for examining the beds situated beneath the Lower Estuarine Clay.

The complete section exposed reveals :-

9. Gravels of the 25-foot raised beach (often reconstituted) :

8. Black sand :

7. Lower estuarine clay:

6. Black sand :

5. Gravel, sub-angular, fine and black:

4. Black sand :

3. Gravel, sub-angular, fine and black :

2. Land surface :

1. Boulder clay containing-cliff rising abruptly on the landward side.

In deposits Nos. 3, 4, 5 and 6 I have found unrolled artefacts of the Early Magdalenian period: these, together with the molluscan and plant remains which the layers in question contain, will be described in the Antiquaries Journal early next year.

30 Southwick Street, J. P. T. BurdhelL.

London, W:2. Oct. 28.

\section{Tunny in the North Sea}

Mr. F. S. Russeld ${ }^{1}$ is certainly correct in assuming that the occurrence of tunny (Thunnus thynnus L.) in the North Sea is not of recent date. The Fisheries staff, during their investigation of herring trawling in 1912 and 1913, frequently observed this magnificent fish in September and October in an area between the Dogger Bank and the coast, and made several (unsuccessful) attempts to capture it. The records made at this time are being extracted from our logbooks and will be available shortly.

Ministry of Agriculture and Fisheries, E. S. Russell.

43, Parliament Street, S.W.1. Nov. 20.

${ }^{1}$ Nature, 132, 786, Nov. 18; 1933.

\section{A Seal in the Thames}

ON November 14, at about 2 p.m., a seal was observed swimming in the Thames between the landing stage and the entrance to the docks at Tilbury, just opposite the Tilbury Hotel. Eventually it climbed up on to the wooden causeway from the hotel gardens to the river and remained there for some time. It appeared to be a three-quarter grown specimen of the common seal, Phoca vitulina, but with the exception of the hind flippers was practically pure white in colour. Passing boats alarmed it and it dived from the causeway several times, and finally disappeared, swimming strongly down-stream.

A. S. BUCKHURST.

Plant Pathological Laboratory, Ministry of Agriculture, Harpenden. Nov. 21. 